\title{
SEISMIC EXPLORATIONS ON THE BELA VODA LOCALITY NEAR BEROVO
}

\author{
Blagica Doneva, Marjan Delipetrev, Gorgi Dimov \\ Faculty of Natural and Technical Sciences, Institute of Geology, "Goce Delčev" University in Štip, \\ Blvd. Goce Delčev 89, 2000 Štip, Republic of North Macedonia \\ blagica.doneva@ugd.edu.mk
}

\begin{abstract}
A b s t r a c t: This paper presents the results from the explorations conducted on the locality Bela Voda, village Dvorište near Berovo. The purpose of the site survey is to determine the potential of the water supplying with underground water according to the represented structural-tectonic and hydrogeological structure, locate and prognostically design exploratory wells for water supply according to the indicated potential, conditions and opportunities for ground water capture. For the needs of the geophysical measurements, field hydrogeological reconnaissance of the terrain has been performed previously. Hydrogeological research and geophysical measurements have been conducted on the locations where hydrogeological characteristics of the terrain and the presence of the types of water bearing environments within the research area have been defined and explained. The investigations are performed by means of reflective seismic scanning of the structural-tectonic assemblage on the terrain by representative investigative profiles and analysis of the known geological data. 10 investigative profiles (RL) with the total length of $1.5 \mathrm{~km}$ were made, of which 2 in the longitudinal direction of the Bela Voda river and 8 in the transverse or normal profiles of the river itself. The field scanning along the investigative profiles was performed with a seismic wave excitation step and a $5 \mathrm{~m}$ distance of geophones and an offset of $10 \mathrm{~m}$. The obtained results from the performed geophysical investigations have confirmed that there is a small zone of Upper Jurassic granite in which a fissure type of aquifer with fissure porosity is formed. For the construction of well exploration (exploitation boreholes) there is a limited potential area, and four potential locations are proposed.
\end{abstract}

Key words: exploration; seismic method; reflection; exploration wells

\section{INTRODUCTION}

The seismic refraction method successfully determines the horizontal, vertical and steep boundary planes, provided that the velocity of the seismic wave propagation in each deeper layer is greater than the velocity in the previous layer. However, when that condition is not fulfilled or when differences in the elastic properties between the individual elastic environments are not sufficiently expressed, and when the boundary planes are at greater depths, the application of the refractive method is uncertain [8].

Therefore, instead of refractive seismic investigations, the reflective method is used. This method is increasingly used with the gradual improvement of the apparatus and the technique of examination, the method of interpretation, and especially with the introduction of computer technique. The reflective seismic method is increasingly adapted to the needs of engineering geology and hydrogeology.

The reflective method determines the depth and inclination of the boundary planes that separate different elastic environments. These parameters are determined by the time it takes the seismic wave (impulse) from the source to reach the geophones positioned on the surface of the terrain along certain paths, but first it is rejecting from the boundary planes existing below the surface of the terrain [10].

The method is based on the principle of wave reflection..

\section{GEOLOGICAL AND HYDROGEOLOGICAL STRUCTURE OF THE INVESTIGATION AREA}

The research site is located within the area of the village of Dvorište in the municipality of Berovo, about $15 \mathrm{~km}$ south of Berovo. The investigation location is reached by the regional road Berovo- 
Strumica, and the use of a forest road in the locality of Bela Voda.

From the geographical and geological point of view, the exploration site is located within the boundary zone of the Ogražden massif with the massif of Maleševski Mountains.

For the purposes of geophysical measurements, field hydrogeological reconnaissance has previously been performed. Hydrogeological surveys and geophysical measurements have been conducted where the hydrogeological characteristics of the terrain and the representation of aquifers' types in the investigative area have been defined and explained [9].

According to the Basic Geological Map of the Republic of Macedonia (1:100 000) [2], Precambrian muscovite-biotite gneisses and Upper Jurassic granites are present in the surface structure of the investigation area and the surrounding terrain (Figure 1). These lithological members are often separated by fault zones in which bodies of amphibolite gabbro are placed and amphibolite laminations appear in the gneisses.

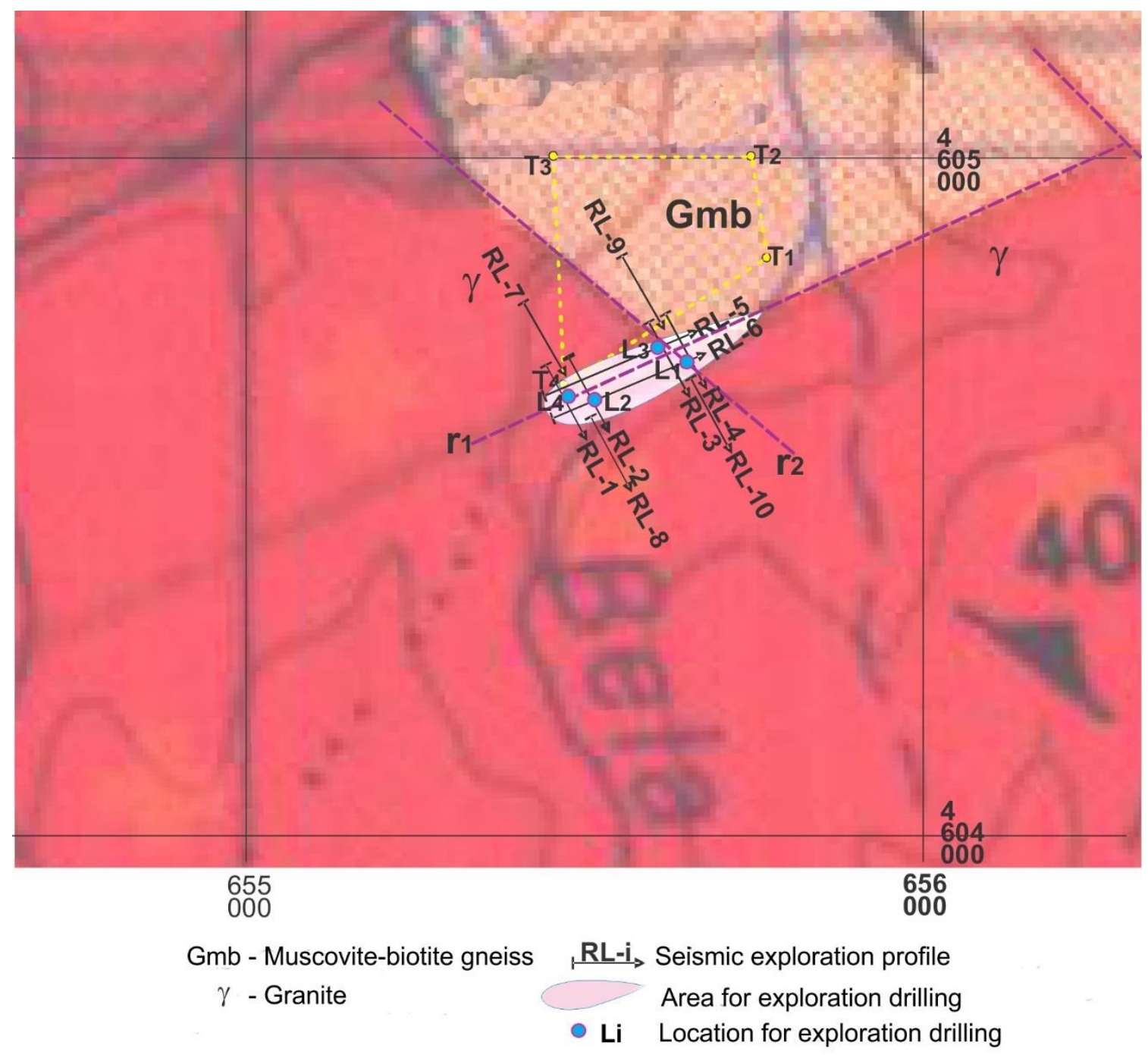

Representative structural model

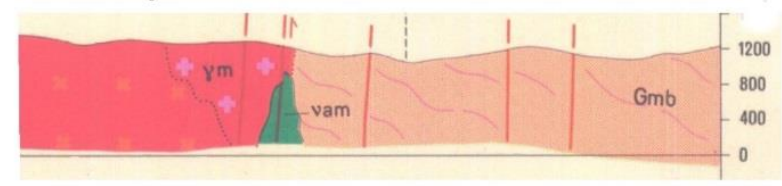

Fig. 1. Geological map of the investigated area with exploration profiles and locations for drilling [2] 
- Two-mica (muscovite-biotite) gneisses

(Gmb) -- are the most idespread types of high metamorphic rocks that are exclusively bound for the Serbian-Macedonian mass. The largest masses are found in the northeast part of the terrain in the areas: Dvorište village, Jami Tepe hill, Klepalo hill, Gabrova Čuka hill. The same rocks extend south to the Bulgarian border.

The two-mica striped gneisses by their distribution and position can be considered to be the basic rocks of the high-metamorphic complex of the given area, and the other metamorphites are facial transitions. In the areas between the Dvorište and Visoka Maala villages, meta-quartz porphyries are with aplitic and pegmatitic wires of smaller dimensions, particularly pronounced east of the Dvorište village.

Two-mica striped gneisses are medium-sized, fine-grained, and locally coarse granular, gray to dark gray in color with a pronounced striped texture. Their structure is lepidogranoblastic and rarely porphyroblastic. For the most part they have a simple mineral composition. The main composers are quartz, K-feldspar, palgioclasses (albit-oligoclasse), biotite and muscovite. The following are ancillary: epidote, coisite, chlorite, garnet, apatite, sphene and ilmenite.

Two-mica stripped gneisses show a gradual transition to other metamorphic Precambrian rocks.

- Muscovite leucocratic granite $(\gamma \mathrm{m})$. These granites occupy the eastern part of the granite batholith and penetrate leptinoliths and micaschists.

These granites are continuation of two-mica porphyroid granites. In these rocks, biotite is almost completely lost, while muscovite is dominant or only present. In addition, these granites show an increased content in potassium feldspars (microcline), which predominate over plagioclasses.

Within the structure of the investigation terrain, beside these two lithological members, there are deluvial (slope sediments and surface damaged rocks up to several meters thick) and proluvial (around the river bed of Bela Voda represented with gravel and dust and clay with a thickness of up to several meters) sediments, amphibolites in the form of lenses in the gneisses and amphibolite gabbro intruded in the fault boundaries of the gneisses and granites [3].

The aforementioned lithological members are characterized by poor fissure porosity and water permeability. From the point of view of accumulation and conduction of ground water, the cracked granites in the surface area of the terrain and in the present fault and crack zones are more interesting. Gneisses are usually characterized by lesser porosity and water permeability than granites. Gabbro intrusions can play an important role in the formation of cracks in the surrounding granites and gneisses. The proluvial and diluvial ground cover is also of low thickness, and together with the elluvial zone they are important mainly from the point of view of lowering surface water into the ground water.

According to the above, following hydrogeological areas can be identified as a subject for reflective seismic scanning of the terrain:

- Surface zone (zone with open cracks) of the terrain composed of granites and gneisses, which usually reached a depth of about 60 to $80 \mathrm{~m}$;

- Deepening of the surface zone of granite and gneisses with fault-crack zones.

Generally, the terrain is a monoclinic structure with a general slope of 30 to $50^{\circ}$ to NE. Schistosity is also present in granites. Granites and gneisses are zones separated by two systems with general directions $\mathrm{Ne}-\mathrm{SW}$ and $\mathrm{NW}-\mathrm{SE}$.

Hydrogeological charactersistics of the present lithological members on the investigated area are the following:

> The proluvial and diluvial sediment is characterized by good intergranular porosity and water permeability, suitable for the formation of underground aquifers, but they appear with low thickness in the surface structure of the terrain and serve only as hydrogeological conductors.

> Amphibolites and gneisses are characterized by poor fissure porosity and water permeability. It can be expected that the fissure porosity will be more pronounced in the surface zones, but from the point of view of water supply, there is practically no significant collector to meet the needs.

Upper Jurassic granites are the only hydrogeological collector in which significant amounts of ground water could be accumulated. According to the geophysical measurements, it is clear that to a depth of about 60 to $80 \mathrm{~m}$ there are cracks in the granites in which a fissure type of aquifer can be formed. But, it is important to note that the same cracks are filled with, probably, a sandy-clay component that can directly affect the yielding of the boreholes. It should be emphasized that only a small part of the explored area is composed of these materials. 
Based on the geological structure and the structural type of porosity of the rock masses within this area, the following types of water bearing areas are found [1]:

- water bearing areas with intergranular porosity and

- water bearing areas with fissure porosity.

According to the hydrodynamic characteristics that are present within the water bearing areas, the following types of wells are present (Figure 2).

- phreatic wells (water body with free ground water level and

- artesian and sub-artesian wells (water bodies with ground water level under pressure).

According their hydrogeological function, the rock masses are separated as:

- hydrogeological collectors,

- hydrogeological conductors and

- hydrogeological isolators.

Rock masses which are characterized with intergranular and fissure porosity are considered to be hydrogeological collectors and conductors.

Within the hydrogeological isolators there are compact and poorly cracked solid rock masses, mainly compact granites, compact gneisses and compact amphibolites. Further are presented all types of aquifers present in this area.

\section{Water bearing areas with intergranular porosity}

This type of water bearing parts in the investigated area, as well as in the wider vicinity of the terrain, does not have much distribution. It is developed within the Quaternary sediments represented by proluvial and deluvial sediments which are composed of poorly treated and untreated pieces of metamorphic and igneous rocks accompanied by gravels, sands and clays. The thickness of these sediments is limited and small and in them an intergranular type of well with intergranular porosity is formed. The filtration characteristics of these sediments are quite good, and they are considered to be a good water bearing medium. However, according to the genesis of the origin of these sediments, it must be emphasized that they accumulate small amounts of ground water and they mainly have the function of hydrogeological conductors.

\section{Water bearing areas with fissure porosity}

This type of aquifers has a large distribution in these areas. It is developed within cracked and tectonically damaged amphibolites, gneisses and granites. The existence of this type of aquifer is clearly seen on the surface of the terrain and it is confirmed by previous geological surveys at the time when the Geological Sheet Strumica at a scale of 1: 100000 was produced.

The ground water in this type of aquifer is generally free and, depending on the hypsometric height of the terrain, but there is also an appearance of artesian and subartesian levels or pressure levels where they occur as springs.

Feeding of ground water of this type of aquifer takes place on a larger area of the OgraždenMaleševo massif through the cracked and tectonically damaged parts of these rock masses.

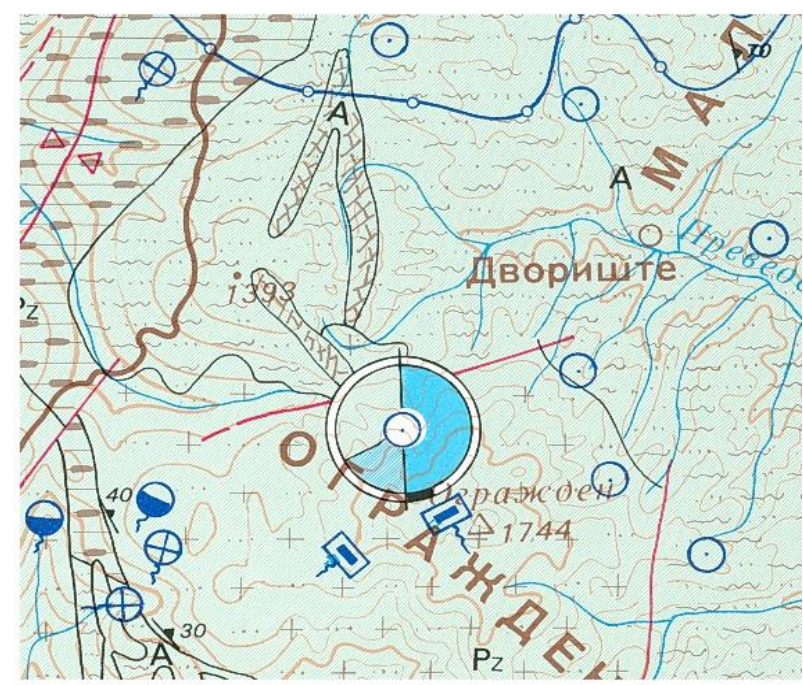

FISSURE TYPE OF SPRINGS

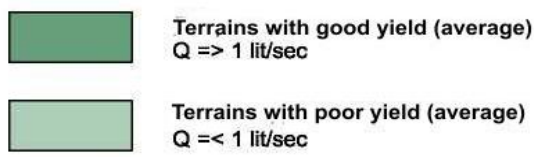

Fig. 2. Cutting of the hydrogeological map of the vicinity of the investigated area [14]

\section{MATHERIALS AND METHODS}

The general principle of seismic reflection is to send elastic waves (using an energy source such as dynamite explosion or vibroseir) into the Earth, where each layer within the Earth reflects a portion of the wave's energy back and allows the rest to refract through. These reflected energy waves are 
recorded over a predetermined time period (called record length) by receivers that detect the motion of the ground in which they are placed. On land, the typical receiver used is a small, portable instrument known as a geophone, which converts ground motion into an analog electrical signal. [5] In water, hydrophones are used, which convert pressure changes into electrical signals. Each receiver's response to a single shot is known as a "trace" and is recorded onto a data storage device, then the shot location is moved along and the process is repeated. Typically, the recorded signals are subjected to significant amounts of signal processing before they are ready to be interpreted and this is a significant area of active research within industry and academia. In general, the more complex the geology of the area under study, the more sophisticated are the techniques required to remove noise and increase resolution $[6,16]$.

The investigations are performed by reflective seismic scanning of the structural-tectonic assemblage on the terrain by representative investigative profiles and analysis of known geological data. 10 investigative profiles (RL) with the total length of $1.5 \mathrm{~km}$ were made, of which 2 in the longitudinal direction of the Bela Voda river and 8 in the transverse or normal profiles of the river itself. The field scanning along the investigative profiles was performed with a seismic wave excitation step and a 5 $\mathrm{m}$ distance of geophones and an offset of $10 \mathrm{~m}[15$, 17].

For the investigations the equipment ABEM TERRALOC Marc 6, 24-channel digital seismograph for seismic surveys was used.

The field scan data are shown in depth seismic sections along the investigation profiles with interpretation. The following lithological environments have been interpreted throughout the terrain along the scanned investigative profiles (Figures 3 to 7 ) [11]:

- Gmb - Precambrian muscovite biotite gneisses;

- $\gamma \mathbf{m}$ - Upper Jurassic two-mica granite.

Due to the low thickness, the proluvial sediment and the surface diluvial-elluvial cover on the deep sections are not interpreted.

\section{RESULTS AND DISCUSSION}

According to the obtained results and interpretation of the depth sections (Figures 3 to 7), a well of underground water can be formed in the surface cracked granites, in the boundary zone with gneisses. This zone is characterized by higher granite cracking, which may be related to the processes of faulty delimitation of granites and gneisses. The registered cracking preliminary can be assessed as weak and with the presence of narrow cracks. In this respect, the real potential of the investigated site for ground water exploitation can be assessed by hydrogeological testing of the investigational wells [7].

For the construction of a well, investigative boreholes are proposed at locations L1, L2 and L3 (Figure 1). Location L1 is assessed as being more potential than locations L2 and L3 in terms of its locations on the intersection of the fault zones $\mathrm{p} 1$ (along which the Bela Voda valley is formed) and p2 (with approximately normal extension of $\mathrm{p} 1$ ). Location L2 is located in the lower terrain in the fault zone $\mathrm{p} 1$. The L3 site is located in the $\mathrm{r} 2$ fault zone and is assessed to have lower potentials than the L1 and L2 locations, as the most suitable terrain location limited to the ground water concession field [12].

The targeted sites for the construction of a well investigative exploitational boreholes L1, L2, L3 and L4 are located in the lithological environment of the granites shown in the geophysical sections (Figures 3 to 7).

According to the expected hydrogeological structure of the granites, the following performance of the Li boreholes can be recommended (Figure 8) [13]:

- Exploratory-exploitational boreholes to be carried out to a depth of about $60-80 \mathrm{~m}$, or up to $5-10 \mathrm{~m}$ in granite with closed cracks, which can be evaluated during drilling mode construction.

- Drilling to be performed with a diameter that enable piping with the diameter of $125 \mathrm{~mm}$, in which an in-depth pump for ground water exploitation can be fitted.

- Initial $10-20 \mathrm{~m}$ depth of boreholes to be protected against inflow of surface water from the surrounding surface area.

- After piping, washing is to be performed, work up and hydrogeological testing of wells to define well capacity and define the exploitational regime of the wells.

To perform complete physical, chemical, bacteriological and radiological analyses of the ground water from all wells to determine their quality. 

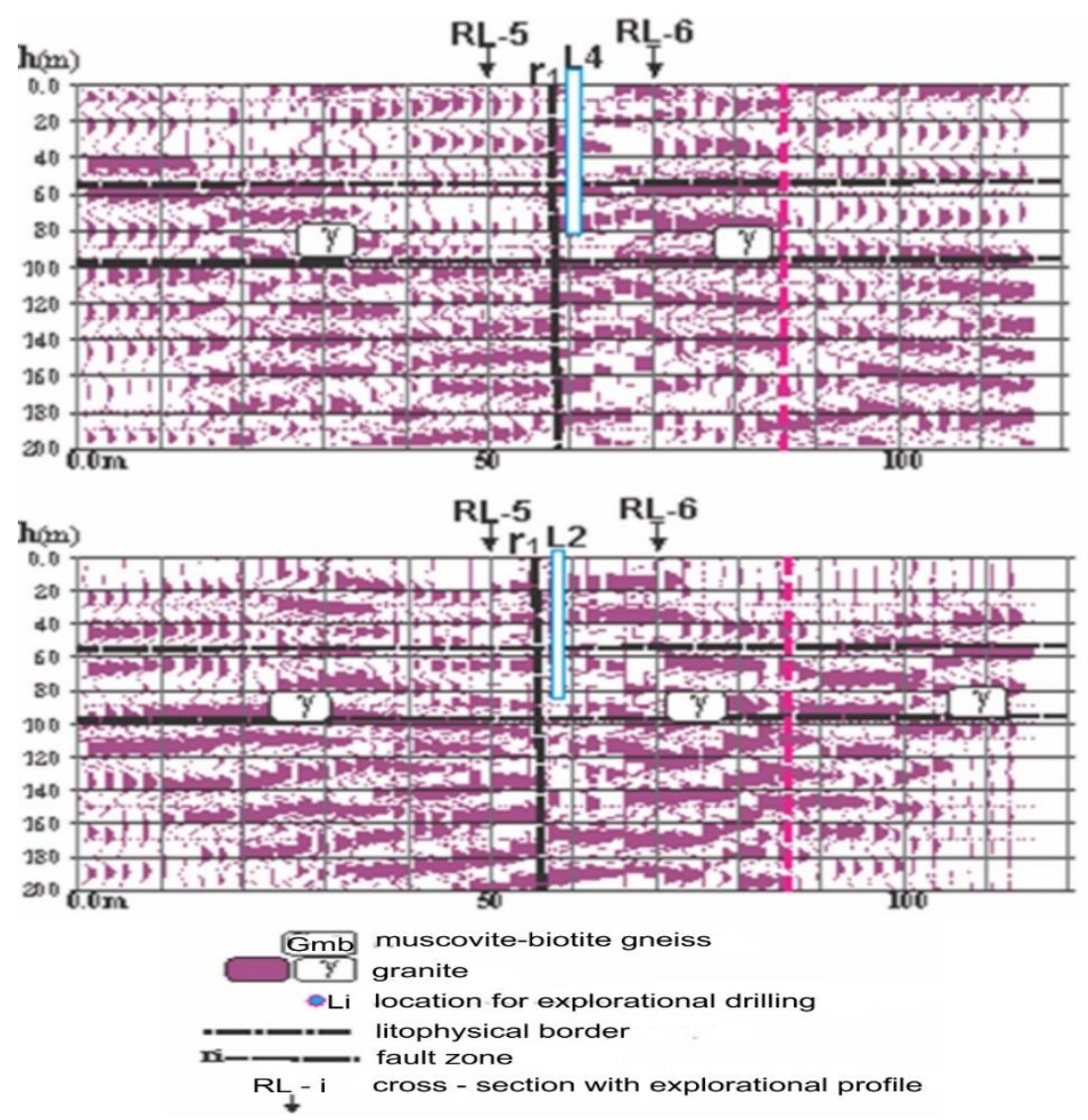

Fig. 3. Depth section with interpretation of profiles RL-5 and RL-6, with L2 and L4
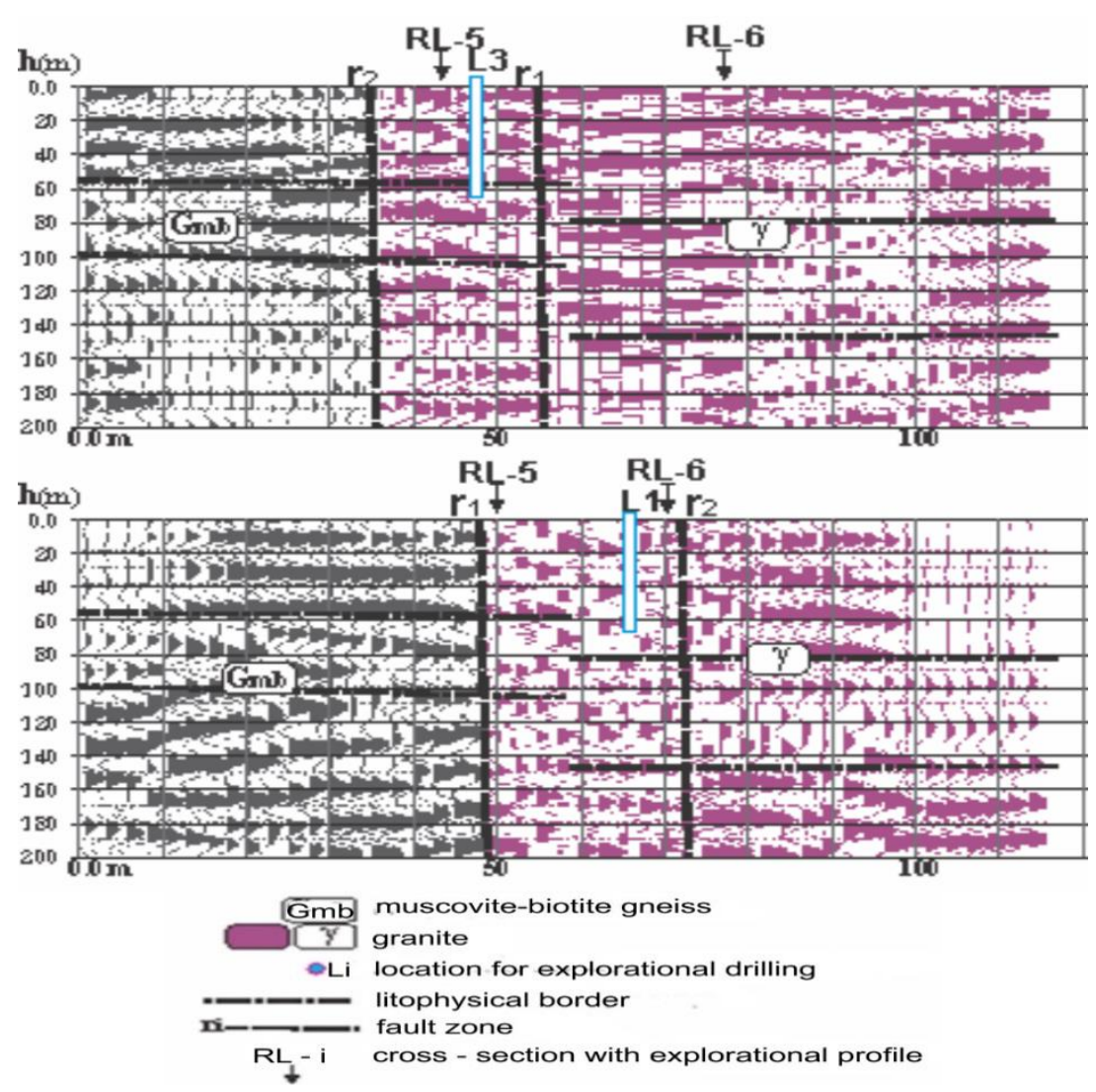

Fig. 4. Depth section with interpretation of profiles RL-5 and RL-6, with L1 and L3 

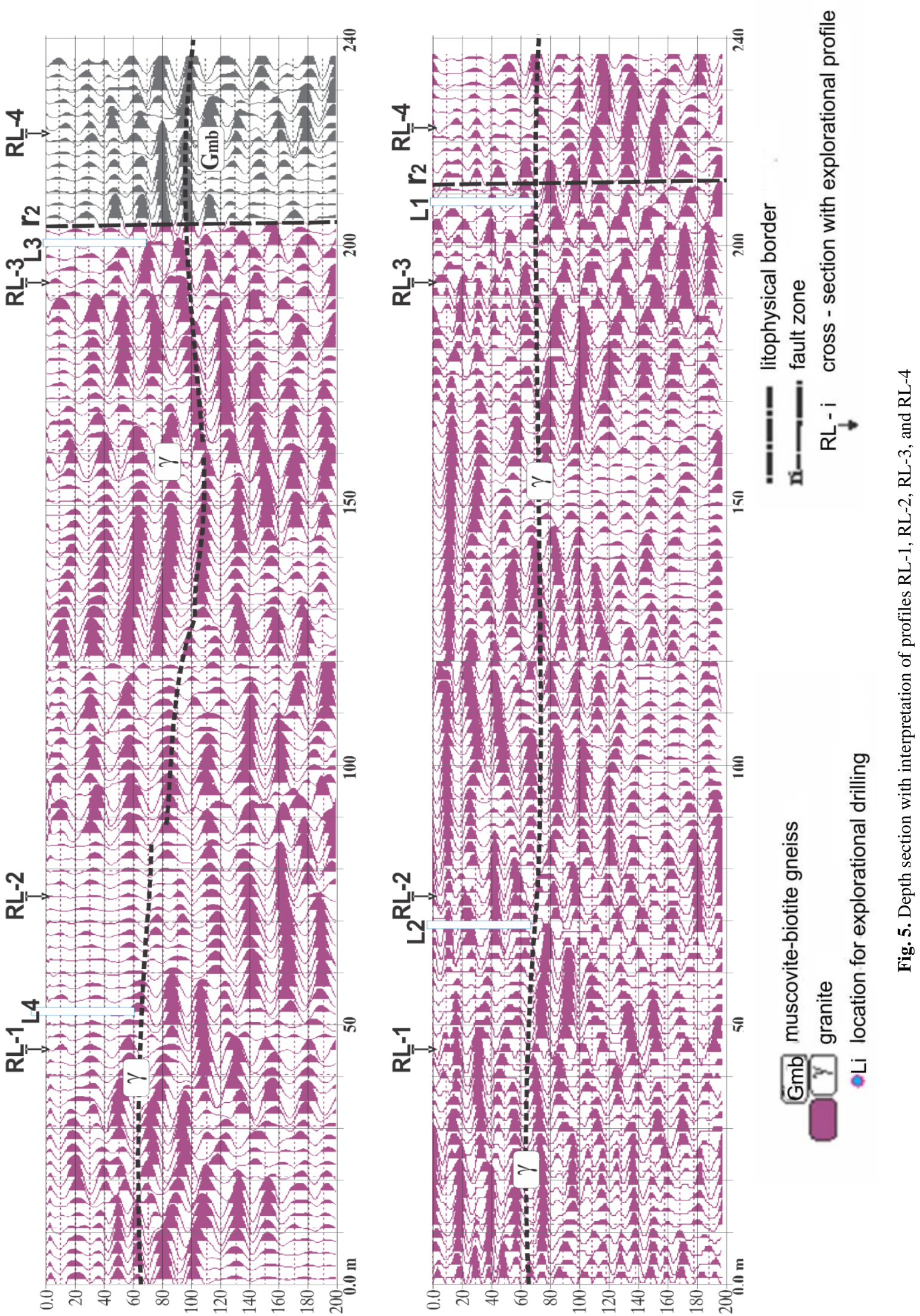

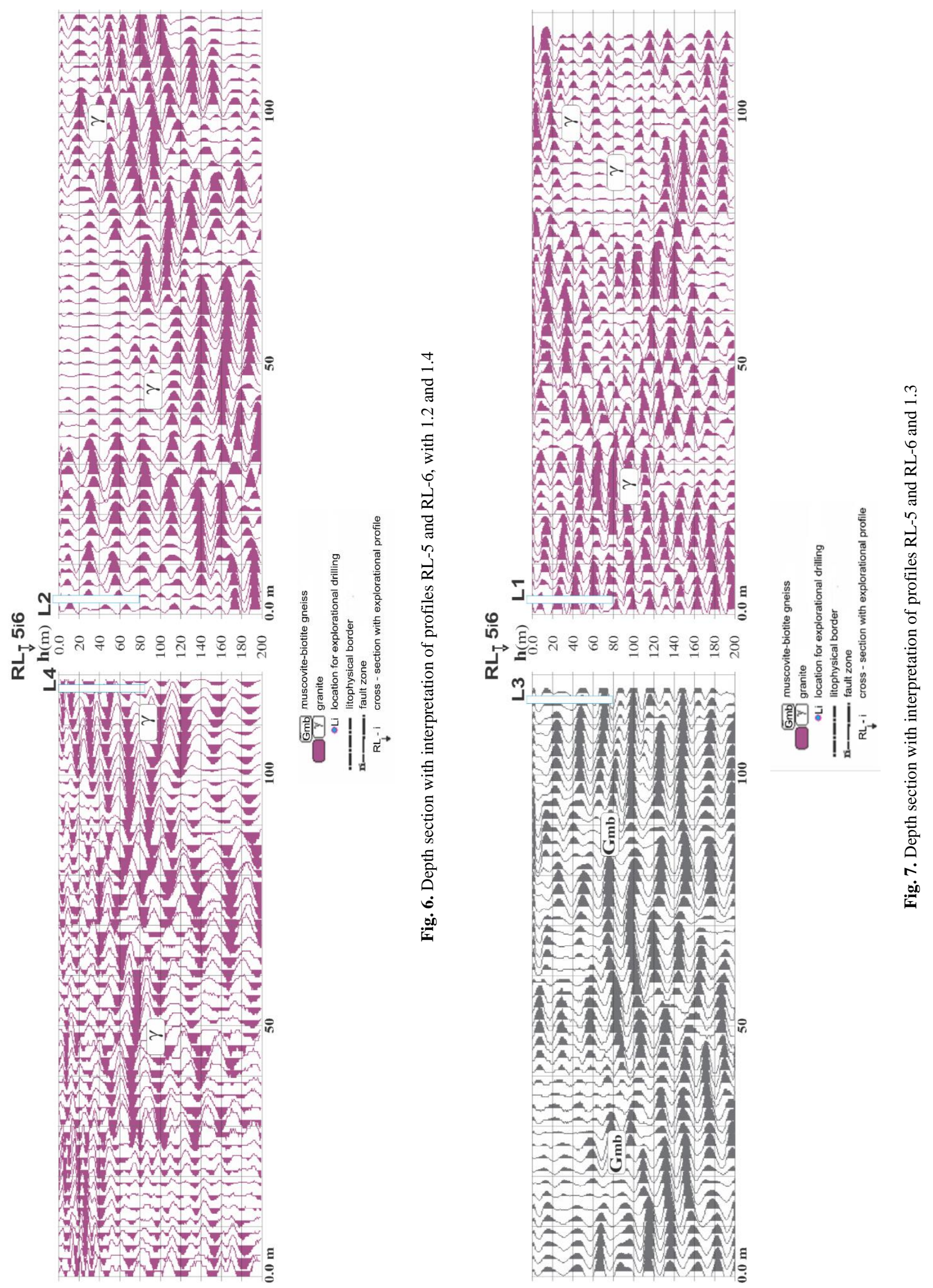


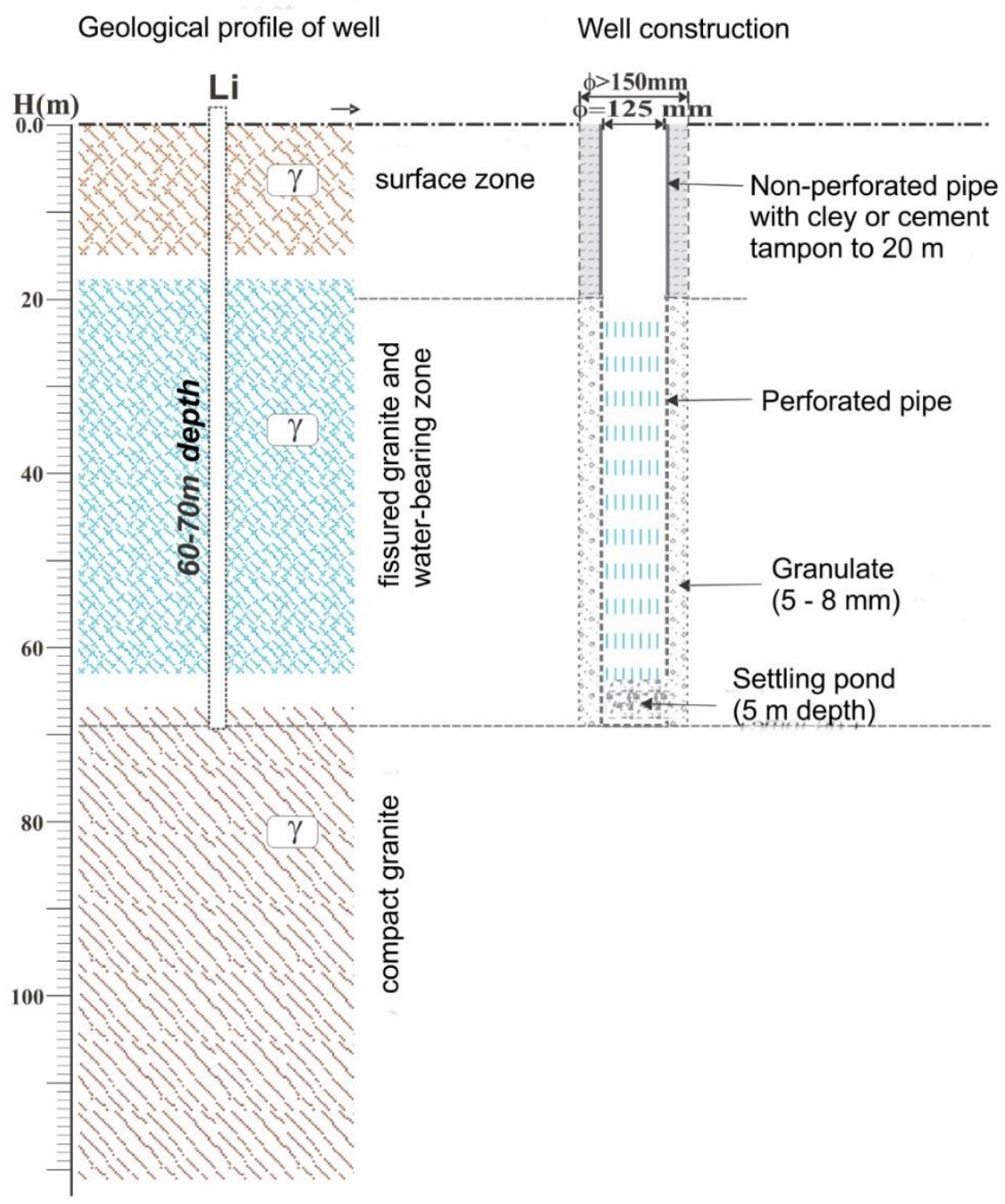

Fig. 8. Construction of exploration well boreholes

\section{CONCLUSION}

The investigations of the potential of the location for ground water supply are performed by reflective seismic scanning of the structural-tectonic structure by representative profiles and analysis of known geological data.

According the obtained results from the performed geophysical investigations, the following conclusions can be presented:

- In the terrain structure, the following hydrogeological environments are present:

- deluvial (slope sediments and surface damaged rocks up to several meters thick) and proluvial (around the bed of the Bela Voda river represented with gravel and dust and clay with the thickness of up to several meters) sediments;
- Precambrian two-mica (muscovite-biotite) gneisses;

- Upper Jurasic granite.

- The terrain of the investigated location has some potential for ground water use.

- Geophysical research has confirmed that there is a small zone of Upper Jurassic granite in which a fissure type of aquifer with fissure porosity is formed. Overall research should focus on these rocks (cracked granites) which are separated as a hydrogeological collector in which certain amounts of ground water can be accumulated. Most of the investigated area is composed of Precambrian muscovite-biotite gneisses which are poorly water-bearing and generally function only as a hydrogeological barrier. 
- For the construction of well explorationexploitation boreholes there is a limited potential area, and it proposed 4 potential locations: L1, L2, L3 and L4.

- According to the obtained hydrogeological structure of the granites, for the construction of the boreholes $\mathrm{Li}$ is recommended to be carried out to a depth of about $60-80 \mathrm{~m}$ with a diameter that enables piping with the diameter of $125 \mathrm{~mm}$, in which an in-depth pump for ground water exploitation can be fitted.

\title{
REFERENCES
}

[1] Geoinženering M Ltd. (2011): Report of performed reflective seismic explorations on location "Bela Voda" near the village Dvorište - Berovo (in Macedonian).

[2] Basic Geological Map of the Republic of Macedonia, sheet Strumica, 1: 100000

[3] Interpreter of the Basic Geological Map of the Republic of Macedonia, sheet Strumica (1980).

[4] Kearey, P., Brooks, M., Hill, I. (2002): An Introduction to Geophysical Exploration. Blackwell Science Ltd. England.

[5] Delipetrov, T. (2003): Basics of Geophysics. Faculty of Mining and Geology. Štip.

[6] Stefanović, D., Martinović, S., Stanić S. (1996): Basics of Geophysics I - Seismic Refraction Method, Seismic Reflection Method, Geophysical Logging. Faculty of Mining and Geology, Belgrade.

[7] Slimak, S. (1996): Engineering Geophysics. Faculty of Mining and Geology. Belgrade.

[8] Dragašević, T. (1983): Seismic Explorations. Geophysical Institute, Belgrade.

[9] Sheriff, R. E., Geldart, L. P. (1995): Exploration Seismology. Cambridge University Press, Cambridge, 592 pp.

[10] Udias, A. (1999): Principles of Seismology. Cambridge University Press, 489 pp.
[11] Yilmaz, O. (2001): Seismic data analysis: processing, inversion, and interpretation of seismic data, Society of Exploration Geophysicists, Tulsa.

[12] Van der Wal, A. (2008): Understanding groundwater \& wells in manual drilling - Instruction handbook for manual drilling teams on hydrogeology for well drilling, well installation and well development, PRACTICA Foundation, Netherlands.

[13] Harter, T. (2003): Water Well Design and Construction, University of California, Division of Agriculture and Natural Resource.

[14] Hydrogeology Map of the Republic of Macedonia 1:200 000, Geological Institute, Skopje, 1977.

[15] Pugin A. J. M., Pullan, S. E., Hunter, J. A., Oldenborger, G. A. (2009): Hydrogeological prospecting using P- and Swave landstreamer seismic reflection methods, Near Surface Geophysics, Willey Online Library, Vol. 7, Issue 5-6, pp 315-328.

[16] Onyebueke, E. O., Manzi, M. S. D., Durrheim, R. J. (2018): High-resolution shallow reflection seismic integrated with other geophysical methods for hydrogeological prospecting in the Nylsvley Nature Reserve, South Africa, Journal of Geophysics and Engineering, Vol. 15, Iss. 6, pp. 2658-2673.

[17] Doneva, B., Tomova, I., Dimov, G., Delipetrev, M. (2019): Geophysical and geotechnical explorations on the fortress Isar - Štip, Geologica Macedonica, Vol. 33, No. 2, pp.147-158.

\section{Р е 3 и м е}

\section{СЕИЗМИЧКИ ИСТРАЖУВАҢА НА ЛОКАЛИТЕТОТ БЕЛА ВОДА ВО БЛИЗИНА НА БЕРОВО}

\author{
Благица Донева, Марјан Делипетрев, Ѓорги Димов

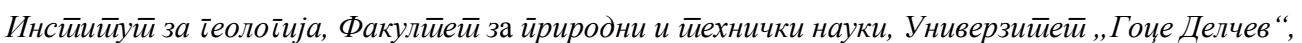 \\ бул. „Гоце Делчев“ 89, 2000 Шӣий, Рейублика Северна Македонија \\ blagica.doneva@ugd.edu.mk
}

Клучни зборови: истражување; сеизмички метод; рефлексија; истражувани дупнатини

Овој труд ги прикажува резултатите добиени од истражувањето на локалитетот Бела Вода, с. Двориште, во близина на Берово. Целта на истражувањето на локацијата е согледување на: потенцијалноста на локацијата за водоснабдување со вода од подземни извори според постојната структурно-тектонска и хидрогеолошка структура; лоцирање и прогнозно проектирање на истражно-експлоатациони дупнатини за водоснабдување според индицираната потенцијалност за водоснабдување. условите и можностите за зафакање на подземните води.

За потребите за геофизичките мерења претходно е изведено теренско хидрогеолошко рекогносцирање на теренот. Спроведени се хидрогеолошки истражувања, дефинирани се геофизички мерења и објаснети се хидрогеолош- 
ките карактеристики на теренот и застапеноста и видот на подземните лежишта на вода во истражуваното подрачје.

Истражувањата се изведени со рефлексивно сеизмичко скенирање на структурно-тектонскиот состав на теренот во репрезентативни истражувани профили и со анализа на познатите геолоши податоци. Истражени се 10 профили $\mathrm{RL}-\mathrm{i})$ со вкупна должина од $1,5 \mathrm{~km}$, од кои 2 по должината на текот на реката Бела Вода и 8 во попречни односно нормални профили на самата река. Скенирањето на составот (структурата) на теренот во истражуваните профили е изведено со побуда на сеизмички бранови и геофонско растојание од $5 \mathrm{~m}$ и со офсет од $10 \mathrm{~m}$.

Добиените резултати од извршените геофизички истражувања потврдија дека постои мала зона на горнојурски гранит во која се формира пукнатински тип на издан со пукнатинска порозност. За изградба на бунарски (експлоатациони) дупнатини има ограничено потенцијално подрачје, а предложени се четири потенцијални локации. 
